Pamiętnik Literacki 2020, 3, s. 268-271

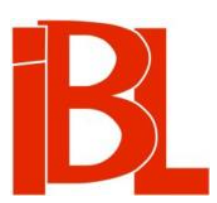

\title{
Wdzięczność niderlandysty
}

Stefan Kiedroń 
STEFAN KIEDROŃ Uniwersytet Wrocławski

ORCID: 0000-0002-3564-7053

\section{WDZIĘCZNOŚĆ NIDERLANDYSTY}

Adam Poprawa w krótkim tekście Kompleks niderlandysty? odniósł się do mojego artykułu o nieznanym szerzej polonicum Justusa Lipsiusa z Biblioteki Uniwersyteckiej we Wrocławiu. Jestem wdzięczny za tę reakcję. Dzięki niej mogę bowiem - w trochę dłuższej wypowiedzi uściślić kilka ważnych według mnie kwestii.

Poprawa rozpoczyna słowami: „Stefan Kiedroń zawiadamia czytelników »Pamiętnika Literackiego", że chodzi do biblioteki”. Potwierdzam: chodzę do biblioteki. A zwłaszcza do Biblioteki Uniwersyteckiej we Wrocławiu. W swoim tekście chciałem podkreślić jej rangę. Otóż BUWr nie jest „którąś tam z kolei”, „siedemnastą” biblioteką uniwersytecką w Polsce; BUWr to biblioteka o znaczeniu europejskim. Niestety: w Polsce jej znaczenie nie jest, moim zdaniem, odpowiednio doceniane.

Dlatego wdzięczny jestem Poprawie za ponowną możliwość podkreślenia tego. Myślę tu przede wszystkim o zgromadzonych w BUWr starych drukach (to „moja” dziedzina). BUWr posiada jedną $z$ największych kolekcji tychże druków - pochodzących $z$ wielu krajów, napisanych w różnych językach i wydawanych w całej Europie ${ }^{1}$. Jak podaje na swojej stronie internetowej Uniwersytet Wrocławski (zachęcając kandydatów na studia), zbiór ten jest „trzeci co do wielkości w Europie” ${ }^{2}$. Cieszę się, że nareszcie - po latach - zauważa się to przynajmniej we Wrocławiu.

Cieszę się też jako (tytułowy u Poprawy) niderlandysta, że mogę doprecyzować i to sformułowanie. Użyłem słowa „niderlandysta”, aby podkreślić, iż Jubilatowi, któremu dedyko-

1 Zob. m.in. A. Sk u r a, Zbiór starych druków Biblioteki Uniwersyteckiej we Wrocławiu jako źródło do badań nad dziejami ksiażki na Śląsku. „Studia o Książce” t. 17 (1988). - J. O żó g, Zarys historii Biblioteki Uniwersyteckiej we Wrocławiu. Wrocław 1995.

2 Vademecum kandydata. Na stronie: https://rekrutacja.uni.wroc.pl/vademecum-kandydata (data dostępu: 14 VIII 2020). 
wany jest zeszyt 2 rocznika CXI „Pamiętnika Literackiego”, życzenia literackie składają n i e ty 1 k o poloniści. Przeczuwałem bowiem, że będą oni stanowili gros autorów tego zeszytu i nie pomyliłem się. Formą trzecioosobową posłużyłem się zaś (co robię bardzo rzadko) właśnie $\mathrm{z}$ takim jubileuszowym nastawieniem.

Mógłbym to określenie rozszerzyć: jestem niderlandystą, ale też germanistą. A mówiąc ogólnie: jestem filologiem. „Philologus” - tak, lubię to słowo. Również dedykacja jubileuszowego zeszytu stawia je na pierwszym miejscu: „Panu Profesorowi / JACKOWI SOKOLSKIEMU / filologowi”. A czy przy tym podpieram się autorytetem Jacka Sokolskiego? Nie, nie podpieram się; kłaniam się z czcią Jubilatowi.

Ale ma rację Poprawa: używam w swoim tekście „nader kwiecistego stylu”. Rozumiem intencję: nie powinienem tak robić. Tym przesłaniem Poprawa nawiązuje - może bezwiednie - do samego Lipsiusa. Ten zwracał bowiem uwagę na to, jak istotna jest brevitas. Jego wybory stylistyczne były jednoznaczne: Tacyt, nie Cycero. Tak i ja powinienem postępować. Także za to wskazanie jestem Poprawie wdzięczny.

A teraz o najważniejszym: o „natężeniu aksjologicznym”. Rzeczywiście, pisząc o Lipsiusie, wyraziłem „stanowcze sądy hierarchiczno-wartościujące”. Powinienem był być, owszem, ostrożniejszy w formułowaniu opinii. Podtrzymuję swoje stwierdzenie, że Lipsius to najwybitniejszy po Erazmie z Rotterdamu myśliciel XVI wieku. Ale - powinienem był doprecyzować przyświecającą mi intencję. Patrząc $z$ perspektywy niderlandystycznej, powinienem był napisać: „najwybitniejszy nide rla nd zki myśliciel po Erazmie”. A patrząc z perspektywy europejskiej - ewentualnie: „najwybitniejszy e p is to lo g r a f po Erazmie”. Środkowe z trzech cytowanych przez Poprawę twierdzeń aksjologicznych oddaje moją myśl najpełniej. Lipsius był według mnie najsłynniejszym uczonym swych czasów.

Bo właśnie w jego czas a ch niemal wszyscy członkowie humanistycznej Republiki Uczonych czytali dzieła Lipsiusa, dyskutowali o nim, chwalili go, krytykowali... Czasy te rozpoczęły się wraz z opublikowaniem w 1584 roku rozprawy De constantia libri duo. Charakterystyczne były słowa Davida Chytraeusa, polihistora i teologa luterańskiego, rektora uniwersytetu w Rostocku: „Kupujcie to, panowie studenci, a czytajcie, bo od tysiąca lat w Philosophicis podobna księga nie była napisana ani widziana" ${ }^{3}$. Sława Lipsiusa trwała jedno, może dwa pokolenia; potem nastapiła zmiana. Ale w swych czasach był on wielki.

Poprawa „konfrontuje” Lipsiusa $z$ innymi autorami i przedstawia ich listę. Ta lista jest intrygujacca - i pozwala na sprecyzowanie kilku kolejnych kwestii „aksjologicznych”.

Jeśli dobrze rozumiem intencję, wymienieni tu myśliciele zasługują na miano większych od Lipsiusa (zdanie „Nie trzeba [...] tak się spieszyć z palmą pierwszeństwa” czytam jako: należy się ona innym). Zgoda, można tak to widzieć. Ale to też jest wartościowanie. Galileusz i dziś, w XXI wieku, zwany jest „ojcem nowoczesnej nauki”. To wyraźne, i najwyższe, wartościowanie.

Idąc dalej: miara Mikołaja Kopernika nie ulega wątpliwości - jako astronoma. Ale czy dzieła jego zwolennika, Giordana Bruna, współczesnego Lipsiusowi, były w ó w c z a s równie szeroko dyskutowane? Główne dzieła Francisa Bacona poświęcone empiryzmowi ukazywały się dopiero w XVII wieku (Of the Proficience and Advancement of Learning rok przed śmiercią Lipsiusa, w 1605 roku; łacińskie tłumaczenie tego dzieła, zatytułowane De dignitate et augmentis scientiarum, dopiero w 1623 roku). Utopia Thomasa More'a ukazała się ponad 30 lat przed urodzeniem się Lipsiusa, a La città del Sole Tommasa Campanelli została opublikowana (jako Civitas Solis) prawie 20 lat po śmierci Lipsiusa; to odstęp ponad

3 Cytuje z przedmowy A. Viritius a do tłumaczenia niemieckiego, Von der Bestendigkeit Zwey Bücher (Gdańsk 1599; wyd. 2: 1601), według edycji: J. Lipsius, Von der Bestendigkeit. (De constantia). Hrsg. L. F or s te r. Stuttgart 1965, k. )(vjr. Przeł. S. K. 
100-letni. Dziękuję za wskazanie - które chętnie przyjmuję - na Michela de Montaigne'a, bardzo przydatne w dyskusji nad stoicyzmem. Oraz nad Seneka.

Jest jeszcze jeden aspekt listy Poprawy. Większość wymienionych postaci pochodzi z południa Europy, przede wszystkim z Italii. Północne krainy nie są tu zbytnio reprezentowane ( $\mathrm{z}$ wyjątkiem Anglii; co do Kopernika - pamiętajmy, że studiował on w Bolonii). To charakterystyczne: polscy badacze (historycy literatury czy historycy sztuki) są w większości właśnie „italianistami”, kierującymi swój wzrok na kulturę włoską. Niezbyt wielu patrzy zaś na kraje położone na północ od Alp (na Cesarstwo, do którego należała też spora część Niderlandów, czy na Skandynawię). A warto: takie spojrzenie zmienia perspektywę badawczą.

Kontynuując hasło „wzmożenie aksjologiczne”, Poprawa stwierdza, że owszem, zdarzają się i dziś takie superlatywy, jak „Mickiewicz - największy poeta polski” czy „Lalka - najlepsza powieść polska”, ale on to odrzuca; „nikt rozważny raczej nie powie” superlatywów o Słowackim, Norwidzie czy o Ferdydurke (jako najlepszej powieści po Lalce).

Mówi się wszakże o kanonie literackim. A to też jest wartościowanie. Witold Gombrowicz ma oczywiście swoją prześmiewczą rację („Za co kochamy Słowackiego?”...). Ale - nawiążę do słów Poprawy - jego Ferdydurke była pierwszą, a więc najważniejszą, powieścią polską umieszczoną w literackim Kanonie na koniec wieku (na piątym miejscu listy; wygrał Michaił Bułhakow). Można się z tym zgadzać, można się nie zgadzać. Zbigniewa Herberta ktoś nazwał „autorem kilku dobrych wierszy”. A czy ja mogę go uważać (bo uważam) za największego polskiego poetę XX wieku?

Dziękuję Poprawie również za wzmiankę o wzmiance Leszka Kołakowskiego. Przy tym, jak sam pisze, jest to „zaledwie wzmianka”. To pokazuje dwie rzeczy - i obie moge tutaj, dzięki niemu, nieco dokładniej przedstawić.

Po pierwsze, fakt, że Kołakowski zamieścił wzmiankę o Lipsiusie, nie musi powodować, że miałaby ona być wskazana przeze mnie. Ja wymieniłem prace Andrzeja Borowskiego, Estery Lasocińskiej i Justyny Dąbkowskiej-Kujko, bo właśnie ci badacze najdogłębniej przedstawiają myśl Lipsiusa (którego Kołakowski, nb., określa mianem „w c z e s n e go humanisty" (podkreśl. S. K.)). Na wymienienie wszystkich publikacji polskich o nim traktujących nie było w moim tekście miejsca. Gdyby jednak takie miejsce się znalazło, to ważniejsze wydawałoby mi się wskazanie nie wzmianki Kołakowskiego, lecz uwag Czesława Hernasa ${ }^{4}$.

Po drugie, „zaledwie wzmianka” u Kołakowskiego potwierdza to, co chciałbym wyrazić: wielki myśliciel z Niderlandów jest w Polsce (zbyt) mało znany. A szkoda - zasługuje na zdecydowanie więcej uwagi niż tylko krótka wzmianka. Właśnie o to mi chodzi: aby przyznać Lipsiusowi należne mu miejsce w badaniach polskich nad kulturą europejską.

Poprawa pyta na końcu: „Któż zresztą wie: być może, Stefan Kiedroń potrafiłby wskazać np. siódmego najwybitniejszego humanistę XVI wieku?"

Wdzięczny jestem również za postawienie tego pytania. Chętnie na nie odpowiem, rozumiejąc przy tym, że określenie „humanista” jest szerokie. Tak więc: kto to mógłby być?

Czy może (idąc tropem Galileuszowym) Duńczyk Tycho Brahe, najwybitniejszy astronom swoich czasów, współczesny Lipsiusowi? Czy może homo universalis Niderlandów z przełomu XVI i XVII wieku, Simon Stevin? Zajmował się on historiozofią i mechaniką, astronomią i geografią, udowodnił, że perpetuum mobile nie może istnieć, skonstruował nowoczesny system ułamków dziesiętnych... Ale miał jedną „wadę”: nie pisał po łacinie, lecz w języku niderlandzkim, który uważał za najlepszy dla nauki język świata...

A może Johannes Sambucus, polihistor, właściciel największej ówcześnie prywatnej biblioteki, dzisiaj wspominany tylko jako autor zbioru emblematów? Albo Joseph Justus

4 O Lipsiusie zob. Cz. Hern a s, Barok. Wyd. 7. Warszawa 1999, s. 155, 178-179, 293, 381. Przy okazji: Herna s nadał rozdziałowi o M. K. Sarbiewskim tytuł Maciej Kazimierz Sarbiewski- „Horacy chrześcijański” (s. 249), z kolei o J. A. Morsztynie napisał: „Mistrz barokowy” (s. 294). 
Scaliger, tak jak Lipsius „wędrujący” między konfesjami, co więcej: jego następca w Lejdzie? Rzadko jest dziś wymieniany, ale w swoim cza sie uważany był za jednego z największych humanistów Europy. Albo Johannes Crato von Krafftheim, którego 500 rocznicę urodzin mogliśmy świętować rok temu? Mogliśmy - ale tego nie zrobiliśmy. Szkoda, że ten słynny w swoim czasie humanista z Wrocławia, Medicus Caesareus trzech władców habsburskich, autor pierwszego opisu sekcji anatomicznej (1576), jest dzisiaj prawie zapomniany.

Nie, ja wskażę inną postać: to mistrz Cratona z Wittenbergi, Philipp Melanchthon. Humanista, profesor języków klasycznych, filozof, poeta. A przede wszystkim: najważniejszy obok Lutra myśliciel protestantyzmu. Ba, może nawet w późniejszym czasie ważniejszy - jako autor Wyznania augsburskiego (Confessio Augustana) z 1530 roku, które do dzisiaj stanowi podstawę teologiczną luteranizmu. To Melanchthon, twórca nowoczesnego systemu uczenia i studiowania, Praeceptor Germaniae, jest dla mnie tą wielką postacią, o którą pyta Poprawa. Cieszę się, że mogłem tę postać tutaj przedstawić. 